\title{
Contingent dynamics of political humour
}

\author{
Sammy Basu \\ Willamette University, USA \\ sbasu@willamette.edu
}

\section{Massih Zekavat}

Alexander von Humboldt Stiftung/Foundation

Europa-Universität Flensburg, Germany

massih.zekavat@uni-flensburg.de

\begin{abstract}
This article introduces the themes of the special issue. It offers a provisional working conception of "political humour." It then notes some of the tendencies and challenges for scholarship on political humour, namely, that political humour interacts contingently and conditionally with intentions, contexts, and audiences. The individual articles of the special issue are briefly summarized, and some concluding lessons drawn.
\end{abstract}

Keywords: communication, democracy, media, political humour, power

Political humour has long dogged the legislative and judicial settings of politics but this is perhaps especially true today. In highly mediated contemporary societies around the world, political humour (comedy, jokes, cartoons, satire, parody, ridicule, etc.) abounds in newspapers, radio programs, and late-night comedy shows, as well as in newer entertaining inflections of mainstream media formats such as cable channel political humour shows and mockumentaries. It further circulates and reverberates electronically in the new genre forms of online tweets, parodies, and memes.

For our purposes, "political humour" does not use political subjects primarily as means for amusement but rather is substantial political action conducted through amusing means. That is, it is political communication that partakes in humour, proffering cognitive and affective pleasures typically resulting in laughter in order to better inform, differentiate, and solicit sympathetic political participation in a particular ideological or distributional agenda in lieu of the agenda of rivals. As such, the rich and growing scholarship on political humour tends to diverge along two lines: emphasising the corrective constraints or the ludic possibilities. That is, scholars either stress the conservative ways in which humour relies upon and redoubles existing shared expectations at the expense of errant targets, or they affirm the radical ways in which it can sponsor cognitive shifts and thereby liberate human energies (see Billig 2005; Lockyer \& Pickering 2005; cf. Demastes 2008; Sørensen 2017). 


\section{The range of humour's contingencies}

Assessing the social functions and practical impacts of political humour (see variously Webb 1981; Nilsen 1990; Paletz 1990; Meyer 2000; Young 2017) is complicated by the ways in which political humour turns on the nature of the political status quo including especially the status quo distribution of power, authority, and membership. In a democratic polity, "conservative" humour (together with apolitical merely entertaining humour) literally presumes or shores up existing hegemonic democratic institutions, values, and participation. Whereas on one side "reactionary" humour undermines democracy in favour of some nostalgic and less inclusive form, on the other "radical" humour presses democratic institutions to engage in further inclusion and fuller representation. Conversely, in an authoritarian political system conservative humour defends the sanctity of established and exclusionary hierarchies against transgressors who in turn lob radical jokes which they hope will produce laughter that shakes those hierarchies to their core (see Boskin 1990; Tsakona \& Popa 2011; Dagnes 2012; Weaver 2016; Pérez 2017).

As a communicative strategy of political action, be it in domestic interactions or foreign relations, the prospects of political humour are further complicated by variations in audience reception. Jokes cast into the (increasingly global) public sphere are rarely uniformly received. Moreover, even those who appear to share in a laugh may be laughing at different dimensions of the joke or satire. Political humour, then, may work to amuse and animate some audiences. Others may register grudging amusement but also be motivated correctively to seek the prospective pleasures of having the last laugh. For still others, humour may prove cathartic and consoling thereby dissipating activist enthusiasm. Jokes can kill but they can also be met with killjoys. They may produce unease and unlaughter in others who disassociate themselves from the prescriptive agenda expressed through the humour. Humour may further prove divisive, prompting counter-joke cycles or more malignly aggressive reactions by targets and their allies (see Smith 2009; Dodds \& Kirby 2013; Chen et al. 2017; Phiddian 2017).

On the whole, there are good democratic reasons to prefer trading punchlines to trading punches. The wide dispersal of political humour can politicise and mobilise viewers into action. However, alternately, it may have the unintended effects of trivialising issues, undermining the purposes of the media, and fostering cynicism and even nihilism, and thereby of discrediting political institutions, office-holders, and politicians, and lowering political trust more generally. Further, political humour that mocks targets may also rally the enactment of humiliating violence against those targets. In short, that politics becomes a joke can go well or badly for the legitimacy and functionality of political institutions (see Barthel \& Moy 2017; Denton \& Voth 2017; Khan 2017; Lee \& Jang 2017; Baumgartner \& Lockerbie 2018; Becker \& Bode 2018).

In implementing this special issue of EJHR we sought original interdisciplinary scholarly work that allowed for both the repressive and irrepressible dynamics of humour by locating the actual practices and instances of political humour succeeding, falling flat, or backfiring within their relevant historical, institutional, and cultural contexts. Though the campaign and election of Donald Trump as US President in 2016 provoked fresh reflections on political humour, we expressly welcomed papers that addressed modern and contemporary non-US and non-Western examples.

Our potential contributors were invited to consider two sorts of questions. First, can we count on humour, comedy, satire and so on to serve salutary and saving roles for democracy and democratisation, and if so, under what conditions? (see Johansen 1991; Basu 1999; Hariman 2008; Becker 2011; McClennen \& Maisel 2016; Davis 2018; Peifer 2012; Innocenti \& Miller 2016). Does political humour (and satire in particular) always level the pretensions of overreaching democratic politicians in favour of the public? Might it instead be adopted by the powerful to pre-emptively goad divisions in their favour within the electorate? When is it an effective foreign relations strategy for advancing democratic regimes? When not? Contextual 
considerations include but are not limited to: who is venturing political humour, within what type of polity, in what sorts of venues, and in the presence of whom? It may well matter if the political humour is articulated by a sitting President or a running politician (see Becker \& Waisanen 2017; Higgie 2017; Smirnova 2018), a stand-up comedian, a patrolling manager, a passing citizen, a hiding dissident, or a wandering exile. Similarly, the public receptivity to and impacts of humorous provocation may well vary with culturally constructed conceptions of honour and face. Second, given the variable and contextual dynamics of the efficacy of political humour what if any ethical duties or social responsibilities might be placed on democraticallyminded practitioners of political humour? Similarly, are citizens in democratic or democratising polities under any civic obligations to try to appreciate humour, especially when doing so amounts to pluralistic self-deprecation?

\section{The articles of this issue}

We were delighted by the quality and range of potential contributions in response to our call on the contingent dynamics of political humour. The sheer volume of this ongoing work suggests that scholars around the world are moving beyond stark and simplifying presumptions about the salience of political humour. Although we did not enjoy having to select from among this rich variety and thereby exclude research of interest and promise, we are very excited to present those that are included here. Bringing together a wide range of essays that explore political humour in Australia, Denmark, Egypt, France, Israel, South Africa, Spain, the UK, and the US, this special issue facilitates a deeper appreciation of the variable interactions and importance of political humour within different contexts. Besides crossing disciplinary and international boundaries, the essays also concern intermedial outlets including pictures, motion pictures, and social media.

In "The Danish Cartoons, Charlie Hebdo and the culture wars: Satiric limits in comparative national and transnational perspectives," Mark Rolfe revisits the two most globally important and tragic recent litmus tests of competing views on the politics of humour in general and satire in particular, namely the Danish Cartoon Controversy of 2005-2006 and the Charlie Hebdo massacre of 2015 in Paris. He does so in order to track the invocation of these examples within both the globally circulating discourse on "culture wars" and its many domestic versions. Engaging with the meta-discourse of humour and its reception, Rolfe finds evidence to caution if not reject the presumption that the politics of satire necessarily entails an antiestablishmentarian agenda that also affirms democracy, freedom, and inclusion. Instead, satire and ridicule are readily deployed and/or selectively rejected in variable rhetorically partisan and populist ways best understood in relation to the contingently national controversies of culture and identity. Rolfe focusses on Australia but also offers illustrations from Israel and the United States.

In "Trevor Noah and the contingent politics of racial joking," Nicholas Holm \& Jennalee Donian focus on one of the most successful transnationally popular political comics operating today. In reviewing two distinct filmed comic performances by Noah, in 2009 in South Africa and in 2018 in the United States, Holm \& Donian offer an insightful reading informed by critical race theory. They find that Noah not only slides back and forth across a continuum from superficial to serious signification but also actively adjusts his comic handling of race to the distinctive cultural and discursive audience expectations in the two contexts. Noah's own being occupies a racially hybrid space and entertains the fluid possibilities of race in the former localised context of South Africa, whereas he has become a comedian of colour on the latter US and global stages subject to closer scrutiny and the responsibility to affirm transnational 
solidarity across seemingly rigid racial categories. In effect, then, according to Holm \& Donian the politics (and ethics) of Noah's comedy shifts contingently.

In "Egyptian Facebook satire: A post-Spring carnivalesque," Yomna Elsayed investigates the role of humour in the political developments during and in the wake of the Arab Spring. More specifically, Elsayed reports on how the Egyptian youth use Facebook as an alternative to mainstream, state-run media in the post-Arab Spring era as an outlet to express dissent. Immediately after the revolution in Egypt, young Egyptians celebrated their newly found freedom by creating and disseminating forms of dissent. When this was met with a resurgence of repressive policies, young Egyptians sought alternative outlets for their satire and humour which had also grown subtler by then. Consequently, they turned to creative humorous works shared through social media to further scrutinise and challenge authority. Historicising and contextualising the Arab Spring and its socio-political background allow the international reader to better appreciate the intricacies of the situation and the use of humour therein. Further, investigating the correlation between political suppression/freedom and the prevalence of verbal/visual humour in a non-Western context foregrounds the sheer significance of shifts in the context in determining the political impact of humour and satire.

The rapid development and increasing reach of social media have dramatically changed the relationship between public followers and mediated authorities be they political or cultural. Twitter has established itself as a new outlet for political discourse in recent years. Although Twitter does not allow for in-depth analysis, meaningful discussion, negotiation and compromise, politicians and activists alike are increasingly utilizing it to reach out to the heartland. Superficially, this platform presents itself as an unfiltered means of communication and connection between any combination of contributors, effectively levelling status. In practice however, it has proved to be less open and democratic. Lacking effective fact-checking processes, it has provided space for the spread of misinformation, fake news, and conspiracy theories. While occasionally facilitating liberationist movements like MeToo, it has frequently given voice to populist leaders and even dictators whose vitriolic posts enflame hatred and violence. Given the absence or inefficacy of regulatory measures in such a vast public space, several functions of satire and humour might surface to intervene in the dynamics of the circulation of power. Their playful tone, vituperating quality, distancing effect, as well as their subversive, exposing, and parrhesic possibilities can ideally be employed in power relations and negotiations to compensate for the scarcity or lack of formal regulations. In their contribution, "Fandom versus citizenship: The 'weirdisation' of politics," Chiaro \& Lobanov draw on celebrities' tweets to make some initial theoretical forays into the study of the impact of this new medium on the fickle dynamics of public awareness and politics.

In a refreshing contribution on the political scene in Asia, Shanon Shah discusses humorous interventions in the 2018 general elections in Malaysia. Although the ruling party employed several repressive measures in influencing election results, Pakatan Harapan (Alliance of Hope, $\mathrm{PH}$ ) finally managed to secure victory despite all the odds. Shah argues that, among other institutional, demographic, and economic factors, spontaneous humour contributed to the political success of PH. His primary contention is that both Mahathir Bin Mohamad and PH employed humour to (re)construct their political identities, which subsequently allowed them to win over the electorate. Shah underscores the interactional roles of mass media, social networks, and political figures in consolidating the political impact of humour.

The scholarly analysis of political humour tends to focus on the verbal and textual. Manuel Garin \& Daniel Pérez-Pamies's contribution pays welcome and innovative attention to the visual media manifestations of contemporary political humour. In "Power and satire in the front page images of Mariano Rajoy: Visual motifs as political humour," they draw upon a wide array of theoretical approaches while focusing on the myriad design and content choices in the use of photographs through which erstwhile serious news media can express partisan perspectives that 
also cue relational and situational humour responses. In particular, they document the satirical visual treatment of the former Prime Minister of Spain, Mariano Rajoy, in three leading Spanish newspapers between 2011 and 2017. Further, and remarkably, they relate the gestural motifs in these photographs to the figurative painting tradition of Spanish royal portraiture, from Velázquez to Goya.

Finally, in "De-contextualisation fuels controversy: the double-edged sword of humour in a hybrid media environment," Sara Ödmark illustrates the ambivalent consequential possibilities of humour. Her focus is on humour in relation to the voices of women and the representations of the Chinese in Swedish media (including TV, radio, and podcasts). Drawing on the four functions of humour as postulated by Meyer (2000) she studies three political controversies involving humour and differentiates three patterns of humorous transgression working on political, socio-cultural, and moral levels. Humour proves to be a politically substantive catalyst in the public debates she investigates. Although its function is not consistent, humour is capable of triggering public debates on political controversies and framing the issue in the media. Moreover, it adds an emotional and visceral dimension to these debates that would be less engaging for the public audience otherwise. Finally, Ödmark also shows how being subject to humour can be manipulated by politicians as an excuse for their impetuous statements and behaviours.

\section{Political humour matters}

The articles in this special issue vigorously investigate a variety of concrete instances of the political interventions of humour. They do so from distinct disciplinary bases and using a mix of methodological approaches. Keeping the range of these contributions in mind (as well as the rich work submitted to us but not included), we would like to venture three general observations regarding the persistence of scepticism about the salience of political humour, the presence of humour in mediated democracies, and the importance of theorising politics and power broadly.

First, scepticism persists regarding the salience of political humour. The late Christie Davies (2011) was perhaps the most notable exponent of the view that humour was a social thermometer, not a thermostat. That is, humour could indicate in compact and memorable ways the tensions and shifts in power structures and societal relationships, but it had no functional capacity to generate those tensions or trigger those shifts. We would acknowledge that much humour that invokes politics does so wholly for entertainment and with negligible effects on societal beliefs and practices. However, given the abundant evidence, including some presented here, we persist in the view that political humour matters not only in reactive ways, but in the proactive and deliberative dimensions of political life.

Second, as a style or strategy of public communication and engagement, political humour has figured notably in democratic contexts. On the one hand, it has been deployed in processes of contestation, efforts at institutional reform and democratization, and patterns of mediated vigilance and criticism of elected leaders. The democratizing roles of humour in the representation of the Other, their relationship with the Self, and granting voice to the unheard are especially pertinent and significant in our present moment. On the other hand, political humour has also been used strategically by elected leaders as means of steering public awareness, defusing legitimate criticism, and even furnishing pre-emptive self-criticism in order to dodge meaningful change.

Third, in assessing the relationship between political humour and actual political power it is necessary to theorise politics not only in terms of the vertical power that is manifested in formal institutions and distributional hierarchies of membership, but also as the horizontal power of discursive fields within which these institutions and members are constituted. Bakhtin 
and Foucault remain for us important sources of theoretical impetus on power as relational discourse in which cognitive claims and formal power are mutually constituted. Conceptualisations of power relations that encompass circulatory rather than top-down flows, and in which institutions, subjects, discourse, and power-knowledge each play a role, can demystify the political implications of humorous intervention. Humour, then, should be understood not only as a weapon of the weak or the strong but as a relational modality implicated in discourse and power, one through which agents and audiences alike can form and manifest oppositional identities (see Bakhtin 2010a, 2010b; Foucault 1970, 1984, 2019; Wilson 2011; Krys et al. 2017; Zekavat 2017).

The topic of political humour, we hasten to add, is far from exhausted. There is still much to do to capture fully the contingent dynamics of political humour. As the etymology of the ludicrous (from Latin lüdicrus, from $l \bar{u} d \bar{o}$ ) suggests, humour invites us to play but also remains intriguingly elusive.

\section{Acknowledgements}

This special issue was initiated in 2018. It has since claimed much time, energy, and dedication from everyone involved and also been dogged by the personal health issues of one of the guest editors and the disruptions of the global pandemic. Throughout, the editors have striven to observe ethical standards and ensure good scientific practice. We express our sincere gratitude to our contributors for their patience and commitment and to the EJHR editors for their advice and support.

\section{References}

Bakhtin, M. M. (2010a). The Dialogic Imagination: Four Essays. Austin: University of Texas Press.

Bakhtin, M. M. (2010b). Speech Genres and Other Late Essays. Austin: University of Texas Press.

Barthel, M. \& Moy, P. (2017). 'The media and the fostering of political (dis) trust', in Kenski, K. \& Jamieson, K. J. (eds), The Oxford Handbook of Political Communication. New York: Oxford University Press, pp. 581-594.

Basu, S. (1999). 'Dialogic ethics and the virtue of humor'. Journal of Political Philosophy 7 (4), pp. $378-403$.

Baumgartner, J. C. \& Lockerbie, B. (2018). 'Maybe it is more than a joke: Satire, mobilisation, and political participation'. Social Science Quarterly 99 (3), pp. 1060-1074.

Becker, A. B. (2011). 'Political humour as democratic relief? The effects of exposure to comedy and straight news on trust and efficacy’. Atlantic Journal of Communication 19 (5), pp. 235250.

Becker, A. B. \& Waisanen, D. J. (2017). 'Laughing or learning with the chief executive? The impact of exposure to presidents' jokes on message elaboration'. Humour 30 (1), pp. 23 41.

Becker, A. B. \& Bode, L. (2018). 'Satire as a source for learning? The differential impact of news versus satire exposure on net neutrality knowledge gain'. Information, Communication \& Society 21 (4), pp. 612-625.

Billig, M. (2005). Laughter and Ridicule: Towards a Social Critique of Humour. London: Sage.

Boskin, J. (1990). 'American political humour: Touchables and taboos'. International Political Science Review 11 (4), pp. 473-482. 
Chen, H. T., Gan, C., \& Sun, P. (2017). 'How does political satire influence political participation? Examining the role of counter-and pro-attitudinal exposure, anger, and personal issue importance'. International Journal of Communication 11 (19), pp. 30113029.

Dagnes, A. (2012). A Conservative Walks into a Bar: The Politics of Political Humor. New York: Palgrave Macmillan.

Davis, J. M. (2018). (Ed.) Satire and Politics: The Interplay of Heritage and Practice. New York: Palgrave Macmillan.

Denton, R. E. \& Voth, B. (2017). 'De-mock-racy: Comic framing as political wrecking ball. In Denton Jr, R. E. \& Voth, B. (eds), Social Fragmentation and the Decline of American Democracy, New York: Palgrave Macmillan, pp. 113-125.

Dodds, K. \& Kirby, P. (2013). 'It's not a laughing matter: Critical geopolitics, humour and unlaughter'. Geopolitics 18 (1), pp. 45-59.

Foucault, M. (1970). The Order of Things: An Archaeology of the Human Sciences. New York: Pantheon.

Foucault, M. (1984). The Foucault Reader. New York: Pantheon.

Foucault, M. (2019). Power: The Essential Works of Michel Foucault 1954-1984. New York: Penguin.

Hariman, R. (2008). 'Political parody and public culture'. Quarterly Journal of Speech 94 (3), pp. 247-272.

Higgie, R. (2017). 'Public engagement, propaganda, or both? Attitudes toward politicians on political satire and comedy programs'. International Journal of Communication 11 (19), pp. 930-948.

Holm, N. (2017). Humour as Politics. New York: Palgrave.

Innocenti, B. \& Miller, E. (2016). 'The persuasive force of political humor'. Journal of Communication 66 (3), pp. 366-385.

Johansen, J. (1991). 'Humour as a political force, or how to open the eyes of ordinary people in social democratic countries'. Philosophy and Social Action 17 (3-4), pp. 23-32.

Khan, A. (2017). Comedies of Nihilism: The Representation of Tragedy Onscreen. New York: Springer.

Krys, K., Xing, C., Zelenski, J. M., Capaldi, C. A., Lin, Z., \& Wojciszke, B. (2017). 'Punches or punchlines? Honor, face, and dignity cultures encourage different reactions to provocation'. Humor 30 (3), pp. 303-322.

Lee, H. \& Jang, S. M. (2017). 'Talking about what provokes us: Political satire, emotions, and interpersonal talk'. American Politics Research 45 (1), pp. 128-154.

Lichter, S. R. (2018). Politics is a Joke!: How TV Comedians are Remaking Political Life. New York: Routledge.

Lockyer, S. \& Pickering, M. (eds.). (2005). Beyond a Joke: The Limits of Humour. New York: Springer.

McClennen, S. \& Maisel, R. (2016). Is Satire Saving Our Nation? Mockery and American Politics. New York: Springer.

Meyer, J. C. (2000). 'Humour as a double-edged sword: Four functions of humour in communication'. Communication Theory 10 (3), pp. 310-331.

Morreall, J. (1983). Taking Laughter Seriously. Albany: State University of New York.

Nilsen, D. L. (1990). 'The social functions of political humor'. The Journal of Popular Culture 24 (3), pp. 35-47.

Paletz, D. L. (1990). 'Political humour and authority: From support to subversion'. International Political Science Review 11 (4), pp. 483-493.

Pérez, R. (2017). 'Racism without hatred? Racist humour and the myth of "colorblindness"'. Sociological Perspectives 60 (5), pp. 956-974. 
Peifer, J. T. (2012). 'Can we be funny? The social responsibility of political humor'. Journal of Mass Media Ethics 27 (4), pp. 263-276.

Smirnova, M. (2018). 'Small hands, nasty women, and bad hombres: Hegemonic masculinity and humour in the 2016 presidential election'. Socius 4, pp. 1-16.

Smith, M. (2009). 'Humor, unlaughter, and boundary maintenance'. Journal of American Folklore 122 (484), pp. 148-171.

Tsakona, V. \& Popa, D. E. (eds.). (2011). Studies in Political Humour: In between Political Critique and Public Entertainment. Amsterdam: John Benjamins.

Wallace, R. (2018). Mockumentary Comedy: Performing Authenticity. New York: Springer.

Waller, J. M. (2017). 'Weaponizing Ridicule'. Military Review Sept-Oct, pp. 49-59.

Weaver, S. (2016). The Rhetoric of Racist Humour: US, UK and Global Race Joking. New York: Routledge.

Webb, R. G. (1981). 'Political uses of humor'. ETC: A Review of General Semantics 38 (1), pp. 35-50.

Wilson, N. (2011). 'Divisive comedy: A critical examination of audience power'. Participations: Journal of Audience and Reception Studies 8 (2), pp. 276-291.

Young, D. (2017). 'Theories and effects of political humor: Discounting cues, gateways, and the impact of incongruities', in Kenski, K. \& Jamieson, K. J. (eds.), The Oxford Handbook of Political Communication. New York: Oxford University Press, pp. 871-885.

Zekavat, M. (2017). Satire, Humour and the Construction of Identities. Amsterdam: John Benjamins. 